\title{
Prosiding Seminar Nasional Kesehatan

\section{Upaya Menjaga Kesehatan Mental Korban Terdampak Banjir Melalui Senam Aerobik Kreasi Di Pekalongan Pada Masa Pandemi}

\author{
Alfira Nuril Aissya $^{1 *}$, Ahmad Khafis ${ }^{2}$, Sugihadi Ilmi ${ }^{3}$, Mega Widya Putri $^{4}$ \\ 1,2,3,4 Program Studi Pendidikan Jasmani, Universitas Muhammadiyah Pekajangan Pekalongan, \\ Indonesia \\ *email: alfiranurilaissya@gmail.com
}

\begin{abstract}
The flood disaster in Pekalongan City in February 2021 has lasted more than 1 week. Several refugee posts have been prepared to accommodate flood-affected communities. The flood that occurred in the midst of the Covid-19 pandemic caused anxiety and concern, both adults and children felt the impact of the flood, as a result most of the residents forgot the PHBS (clean and healthy lifestyle) habits and did not comply with the $4 \mathrm{M}$ health protocol (wearing masks, washing clothes). hands, keeping a distance, and avoiding crowds) while at the evacuation post. This situation cannot be allowed to drag on, continuous anxiety and worry can lower a person's immune system so that they have the opportunity to contract the Covid19 virus. The purpose of this service is to remind the community about the importance of maintaining PHBS (clean and healthy lifestyle) and complying with the $4 \mathrm{M}$ health protocol (wearing masks, washing hands, maintaining distance, avoiding crowds), and reducing public anxiety and concern. The method used in this service is public education related to PHBS and $4 \mathrm{M}$ as well as trauma healing by doing creative aerobics. The results of this service are increasing public awareness regarding the implementation of PHBS (clean and healthy lifestyle) and continuing to carry out $4 \mathrm{M}$ (wearing masks, washing hands, keeping distance, avoiding crowds) in the refugee environment and increasing physical fitness, and providing joy, so that these activities help reduce the anxiety, worry and fear experienced by floodaffected communities.
\end{abstract}

Keyword: community education; evakuation; flood; trauma healing

\section{Abstrak}

Banjir di Kota Pekalongan pada bulan Februari 2021 sudah berlangsung lebih dari 1 pekan. Beberapa pos pengungsian sudah disiapkan untuk menampung masyarakat terdampak banjir. Banjir yang terjadi ditengah pandemi Covid-19 menyebabkan kecemasan dan kehawatiran, baik orang dewasa maupun anak anak ikut merasakan dampak dari banjir tersebut. Akibatnya sebagian besar warga melupakan kebiasaan PHBS (pola hidup bersih dan sehat) dan tidak mematuhi protokol kesehatan 4M (memakai masker, mencuci tangan, menjaga jarak, dan menghindari kerumunan) ketika berada di pos pengungsian. Keadaan ini tidak bisa dibiarkan berlarut larut, kecemasan dan kehawatiran yang terus menurus dapat menurunkan imunitas tubuh seseorang sehingga berpeluang terjangkit virus Covid-19. Tujuan pengabdian ini dilakukan untuk mengingatkan kembali kepada masyarakat tentang pentingnya menjaga PHBS (pola hidup bersih dan sehat) dan mematuhi protokol kesehatan 4M (memakai masker, mencuci tangan, menjaga jarak, menghindari kerumunan), dan mengurangi kecemasan serta kehawatiran masyarakat. Metode yang digunakan dalam pengabdian ini ialah pendidikan masyarakat terkait PHBS dan 4M serta trauma healing dengan melakukan senam aerobik kreasi. Adapun hasil dari pengabdian ini adalah meningkatnya kesadaran masyarakat terkait penerapan PHBS (pola hidup bersih dan sehat) dan tetap melaksanakan 4M (memakai masker, mencuci tangan, menjaga jarak, menghindari kerumunan) dilingkungan pengungsian dan meningkatnya kebugaran jasmani, dan 


\section{Prosiding Seminar Nasional Kesehatan Lembaga Penelitian dan Pengabdian Masyarakat Universitas Muhammadiyah Pekajangan Pekalongan}

memberikan kegembiraan, sehingga aktivitas tersebut membantu mengurangi rasa cemas, khawatir dan takut yang dialami oleh masyarakat yang terdampak banjir.

Kata kunci: Banjir; pengungsian; pendidikan masyarakat; trauma healing

\section{Pendahuluan}

UU Nomor 24 Tahun 2007 Tentang Penanggulangan Bencana, definisi bencana adalah peristiwa atau rangkaian peristiwa yang mengancam dan mengganggu kehidupan dan penghidupan masyarakat yang disebebkan, baik oleh faktor alam dan atau non alam maupun faktor manusia sehingga mengakibatkan timbulnya korban jiwa manusia, kerusakan lingkungan, kerugian harta benda, dan dampak psikologis. [1]. Kota Pekalongan terletak di dataran rendah pantai utara Pulau Jawa dengan ketinggian lahan antara satu meter diatas permukaan laut pada wilayah bagian utara dan enam meter diatas permukaan laut pada wilayah bagian selatan. Ditinjau dari kemiringan lahan, Kota Pekalongan termasuk daerah yang relatif datar, yaitu dengan kemiringan lahan rata-rata antara 0-5\%, serta permukaan Kota Pekalongan sangat berfluktuatif sesuai dengan musim (musim hujan permukaan air naik dan pada musim kemarau permukaan air turun). Pada musim hujan ketika permukaan air naik cenderung menahan aliran air dari anak-anak sungai kecil yang bermuara di Kota pekalongan, sehingga mengakibatkan aliran balik ke anak-anak sungai tersebut (back water effect) lebih-lebih lagi bila air laut dalam kondisi pasang naik, sehingga mengakibatkan munculnya genangan-genangan yang bersifat musiman. [2]

Menurut penjelasan letak topografi diatas, daerah Pekalongan sangat rawan terjadi banjir. Intensitas hujan yang sangat tinggi ditambah dengan tigginya gelombang air laut menyebabkan sejumlah wilayah yang ada di Kota Pekalongan tergenang air. Sejak pertengahan Januari 2021, intensitas hujan yang sangat tinggi mengguyur wilayah Pekalongan. Hal ini menyebabkan beberapa titik daerah di Kota Pekalongan mengalami banjir yang sangat parah hingga ketinggian air mencapai rata rata $50 \mathrm{~cm}$. Tingginya air yang merendam pemukiman, mengharuskan warga mengevakuasi diri, beberapa titik pengungsian pun sudah disediakan oleh Pemerintah Kota Pekalongan dan beberapa organisasi kemasyarakatan untuk menampung warga yang membutuhkan tempat pengungsian. Kejadian ini tentunya menciptakan duka dan kekhawatiran yang mendalam bagi warga yang terdampak. Bukan hanya orang dewasa anak anak pun ikut merasakan dampak dari bencana ini yakni kepanikan dan lelah.

Telah tampak kerusakan di darat dan di laut disebabkan perbuatan tangan manusia; Allah menghendaki agar mereka merasakan sebagian dari (akibat) perbuatan mereka, agar mereka kembali (kejalan yang benar). (Q.S.ar- Rum/30:41).[3]. Jika kita melihat dari Al-Quran Surat Ar-Rum ayat 41 bahwasannya terjadinya bencana itu diakibatkan oleh ulah manusia itu sendiri. Manusia adalah makhluk yang tidak dapat menghasilkan energi sendiri, hendaknya kita sebagai manusia tetap menjaga, dan merawat alam dan lingkungan kita. Bagaimanapun keadaannya manusia hidup bergantung dengan alam, dengan tidak merusak alam adalah salah satu cara termudah untuk menjaganya. Alam adalah rahmat dari Allah dimana semua kebutuhan manusia ada di dalamnya termasuk oksigen untuk kita bernafas, air sebagai kebutuhan kita sehari hari, tanah dimana kita bisa tinggal di atasnya dan flora fauna yang yang 


\section{Prosiding Seminar Nasional Kesehatan $\mathbf{2 0 2 1}$ Lembaga Penelitian dan Pengabdian Masyarakat Universitas Muhammadiyah Pekajangan Pekalongan}

turut ikut mengindahkan alam ini. Tidak hanya amal baik kepada manusia, amal baik kepada alam pun perlu kita tanamkan. Datangnya bencana merupakan peringatan Allah agar kita selalu berada di jalanNya, bagaimana kita menyikapi sebuah musibah dengan mensyukuri apa yang kita miliki hingga datanglah musibah dengan mengambil kembali segala yang hanya menjadi titipan. Selain itu kita sebagai hamba Allah harus senantiasa bersyukur dan tetap ber-amar ma'ruf nahi mungkar yang artinya menjalankan perintah Allah serta menjauhi larangannya agar alam ini tetap terjaga keseimbangannya.

Menurut keterangan beberapa warga, banjir yang terjadi di Kota Pekalongan tentunya menyebabkan sejumlah kerugian yang dialami masyarakat dimana sebagian harta benda harus rusak terendam air. Selain itu, banjir juga mengakibatkan kehawatiran dan kecemasan yang berpengaruh pada suasana masyarakat pengungsian. Situasi ini menjadikan kesadaran masyarakat akan pentingnya pola hidup bersih dan sehat ditengah pandemi berkurang. Terbatasnya tempat pengungsian dan banyaknya warga yang datang untuk mengungsi juga menjadi kendala bagi masyarakat untuk melaksanakan protokol kesehatan, hingga banyak warga di pengungsian yang tidak memperhatikan jarak satu sama lain bahkan tidak memakai masker. Masyarakat dan pemerintah setempat pun sudah banyak memberikan bantuan berupa materi, namun selain itu masyarakat terdampak banjir membutuhkan bantuan psikis untuk mengurangi kecemasan yang diakibatkan oleh bencana yang sedang terjadi. Pengabdi sebelumnya sudah melakukan metode trauma healing untuk anak terdampak bencana alam melalui terapi bermain, namun pada pengabdian kali ini kami menggunakan metode trauma healing yang ditujukan untuk masyarakat umum melalui senam aerobic. Melihat kondisi demikian kami mahasiswa Pendidikan Jasmani Universitas Muhammadiyah Pekajangan Pekalongan turut serta dalam upaya memperbaiki keadaan dalam bentuk pengabdian masyarakat yang bekerja sama dengan LKP Rafika mengadakan kegiatan yang bersifat mengedukasi melalui pendidikan masyarakat untuk tetap menjalankan PHBS (pola hidup bersih dan sehat) dan 4M (memakai masker, mencuci tangan, menjaga jarak, menghindari kerumunan) sekaligus memberikan trauma healing melalui senam aerobic yang bertujuan untuk menghilangkan kecemasan dan kehawatiran yang dialami masyarakat serta meningkatkan kebugaran jasmani. Dengan judul kegiatan "Upaya Menjaga Kesehatan Mental Korban Terdampak Banjir Melalui Senam Aerobik Kreasi Di Pekalongan Pada Masa Pandemi"

\section{Literature Review}

Pengabdian masyarakat yang kami lakukan dengan judul "Pendidikan Masyarakat dan Trauma Healing Pada Korban Banjir Pekalongan di Pengungsian Tahun 2021" terdapat kesamaan tema dari artikel yang pernah kami baca yaitu artikel dengan judul Terapi Bermain Sebagai Trauma Healing Pada Anak Korban Bencana Alam Kampung Belelang Kecamatan Manganitu Kabupaten Kepulauan Sangihe yang ditulis oleh Dhito Dwi Pramardika dari Politeknik Negeri Nusa Utara. Dalam artikel tersebut memuat pembahasan mengenai pemulihan trauma pada anak korban bencana alam yang terjadi di Kampung Belelang, Kecamatan Manganitu Kabupaten Kepulauan Sangihe Provinsi Sulawesi Utara. Pemulihan dilakukan dengan cara mengajak anak melakukan 


\section{Prosiding Seminar Nasional Kesehatan Lembaga Penelitian dan Pengabdian Masyarakat Universitas Muhammadiyah Pekajangan Pekalongan}

beberapa kegiatan sehingga anak anak teralihkan dari suasana kesedihan, kegiatan tersebut diantaranya, mewarnai, bernyanyi, bermain kelereng, dan bermain ular tangga. [4]

\section{Metode}

Kegiatan pengabdian masyarakat yang dilakukan dipengungsian SMK N 2 Kota Pekalongan menggunakan metode pendidikan masyarakat serta pemberian trauma healing. Edukasi protokol kesehatan merupakan hal pertama yang kami sampaikan kepada masyarakat tentang pentingnya PHBS (pola hidup bersih dan sehat) serta kami memberikan himbauan kepada masyarakat untuk tetap menerapkan 4M yaitu mencuci tangan, memakai masker, menjaga jarak, dan menghindari kerumunan merupakan hal wajib yang harus diterapkan selama berada dilingkungan pengungsian. Selanjutnya kami memberikan trauma healing kepada masyarakat melalui senam aerobik kreasi yang dipimpin oleh LKP Rafika.

Dalam kegiatan ini kami menggunakan pendekatan pelatihan dan pendampingan secara langsung untuk mengetahui respon masyarakat akan hasil dari kegiatan ini, musik pop dan dangdut yang sedang populer juga kami manfaatkan untuk mengiringi senam aerobic kreasi, dengan dibantu oleh petugas pos pengungsian untuk mengoperasikan pengeras suara yang sudah disediakan oleh pihak pengungsian.

\section{Hasil dan Pembahasan Hasil}

Kegiatan pendidikan masyarakat dan trauma healing merupakan rangkaian dari runtutan kegiatan pengabdian masyarakat. Kegiatan pengabdian masyarakat yang dilakukan bertujuan untuk meningkatkan perilaku kesadaran masyarakat dalam menerapkan PHBS (pola hidup bersih dan sehat) dan 4M (memakai masker, mencuci tangan, menjaga jarak, menghindari kerumunan) dilingkungan pengungsian.

Menurut Skinner yang dikutip oleh Notoatmojo (2003), Perilaku merupakan respon atau reaksi seseorang terhadap stimulus atau rangsangan dari luar. Oleh karena itu perilaku yang terjadi melalui proses adanya stimulus terhadap organisme dan kemudian organisme tersebut merespon. Pendapat lain juga dikemukakan oleh Reward dan Reinforcement, menurut pendapat mereka, laku seseorang senantiasa berdasarkan kondisi, yaitu tindakan mengenal atau berbicara seseorang terlibat langsung dalam situasi itu dan memperoleh insight untuk menangani masalah. [5]

Kementrian Kesehatan menjelaskan "PHBS adalah sebuah rekayasa sosial yang bertujuan menjadikan sebanyak mungkin anggota masyarakat sebagai agen perubahan agar mampu meningkatkan kualitas perilaku sehari-hari dengan tujuan hidup bersih dan sehat. Tujuan utama dari gerakan PHBS adalah meningkatkan kualitas kesehatan melalui proses penyadartahuan yang menjadi awal dari kontribusi individu - individu dalam menjalani perilaku kehidupan sehari-hari yang bersih dan sehat. Manfaat PHBS yang paling utama adalah terciptanya masyarakat yang sadar kesehatan dan memiliki bekal pengetahuan dan kesadaran untuk menjalani perilaku hidup yang menjaga kebersihan dan memenuhi standar kesehatan." [6]

Selain PHBS (pola hidup bersih dan sehat) menerapkan protokol kesehatan 4M diantaranya memakai masker, mencuci tangan, menjaga jarak dan menghindari 


\section{Prosiding Seminar Nasional Kesehatan $\mid 2021$ Lembaga Penelitian dan Pengabdian Masyarakat Universitas Muhammadiyah Pekajangan Pekalongan}

kerumunan merupakan hal penting yang wajib dipatuhi sebagai upaya pencegahan terhadap wabah Covid-19 yang semakin meluas. Masyarakat dilingkungan pengungsian banjir Kota Pekalongan terlihat masih belum menerapkan PHBS (pola hidup bersih dan sehat) dan 4M (memakai masker, mencuci tangan, menjaga jarak, menghindari kerumunan), dibuktikan dengan banyaknya warga yang belum memakai masker dan tidak menjaga jarak satu sama lain saat di pengungsian. Hal ini disebabkan karena banyaknya pengungsi yang tinggal sehingga tempat yang tersedia memenuhi kapasitas.

Situasi pandemi bukanlah situasi yang bisa dianggap remeh, dalam situasi apapun sebisa mungkin masyarakat harus tetap menerapkan PHBS (penerapan pola hidup bersih dan sehat) dan 4M (memakai masker, memcuci tangan, menjaga jarak, dan menghindari kerumunan). Kesadaran masyarakat ditempat pengungsian masih sangat kurang dalam penerapan PHBS (pola hidup bersih dan sehat) dan 4M (memakai masker, mencuci tangan, menjaga jarak, menghindari kerumunan). Pendidikan kepada masyarakat dengan mengingatkan kembali tentang pentingnya PHBS (pola hidup bersih dan sehat) dan menerapkan kebiasaan 4M (memakai masker, mencuci tangan, menjaga jarak, menghindari kerumunan), yaitu memakai masker, mencuci tangan, menjaga jarak dan menghindari kerumunan, merupakan kegiatan yang sangat penting untuk di sampaikan ditengah masa pandemi yang belum usai.

Ditengah pandemi Covid-19 yang belum berakhir, hujan yang terus mengguyur wilayah Pekalongan mengakibatkan sejumlah wilayah tergenang air sehingga Pemerintah Kota Pekalongan mengeluarkan status darurat banjir pada tanggal 7 - 20 Februari 2021. Hal ini menambah kehawatiran dan kecemasan masyarakat Kota Pekalongan terkait banjir yang semakin tinggi atau banjir susulan. Menurut UU Nomor 24 Tahun 2007 Tentang Penanggulangan Bencana, "definisi bencana adalah peristiwa atau rangkaian peristiwa yang mengancam dan mengganggu kehidupan dan penghidupan masyarakat yang disebebkan, baik oleh faktor alam dan atau non alam maupun faktor manusia sehingga mengakibatkan timbulnya korban jiwa manusia, kerusakan lingkungan, kerugian harta benda, dan dampak psikologis." (Badan Penanggulangan Bencana Daerah Kabupaten Tanah Laut, 2018)

Bencana banjir di Kota Pekalongan menimbukan sejumlah kerugian seperti yang disampaikan UU Nomor 24 Tahun 2007 Tentang Penanggulangan Bencana, diantaranya masyarakat mengalami kerugian harta benda dan dampak psikologis. Dari kerugian tersebut masyarakat mengalami kecemasan, ketakutan, dan kepanikan, maka diperlukkan kegiatan trauma healing yang bertujuan untuk menurunkan tingkat kecemasan, ketakutan, dan kepanikan tersebut. Trauma adalah keadaan jiwa atau tingkah laku yang tidak normal sebagai akibat dari tekanan jiwa atau cedera jasmani. (KBBI). Sehingga dapat disimpulkan bahwa Trauma healing merupakan satu proses pemberian bantuan berupa penyembuhan untuk mengurangi gangguan psikologis seperti kecemasan, panik, dan gangguan lainnya karena lemahnya ketahanan fungsi fungsi metal yang dimiliki individu korban bencana alam tersebut. Kegiatan trauma healing merupakan salah satu rangkaian dari kegiatan pengabdian masyarakat yang kami lakukan. tujuan dari trauma healing adalah untuk menurunkan tingkat kecemasan dengan kegiatan yang menyenangkan. 


\section{Prosiding Seminar Nasional Kesehatan 2021 Lembaga Penelitian dan Pengabdian Masyarakat Universitas Muhammadiyah Pekajangan Pekalongan}

Hasil dari kegiatan pengabdian masyarakat ini ialah meningkatnya kesadaran masyarakat akan pentingnya penerapan PHBS (pola hidup bersih dan sehat) dan tetap memaksimalkan 4M (memakai masker, mencuci tangan, menjaga jarak, menghindari kerumunan) dilingkungan pengungsian sebagai langkah memutus mata rantai penyebaran Covid-19, kemudian pemberian trauma healing melalui senam aerobic kreasi. Senam aerobik adalah serangkaian gerakan yang dilakukan beriringan dengan irama musik dalam durasi waktu tertentu. Senam aerobik dikenal pula dengan istilah kardio. [7]. Dengan senam aerobik masyarakat mendapatkan manfaat yang sangat luar biasa seperti meningkatnya kebugaran jasmani, dan memberikan kegembiraan, sehingga aktivitas tersebut membantu mengurangi rasa cemas, khawatir dan takut yang dialami oleh masyarakat yang terdampak banjir. Dari hasil pendekatan dan pendampingan secara langsung masyarakat juga mengaku senang dengan adanya kegiatan ini, selain mengingatkan mereka akan pentingnya protokol kesehatan, masyarakat juga dapat berolahraga dan berkesempatan menyampaikan keluhan kesehatan kepada instruktur senam. Bahkan sebagian dari masyarakat yang berada di pengungsian berharap kegiatan serupa bisa dilaksanakan kembali.

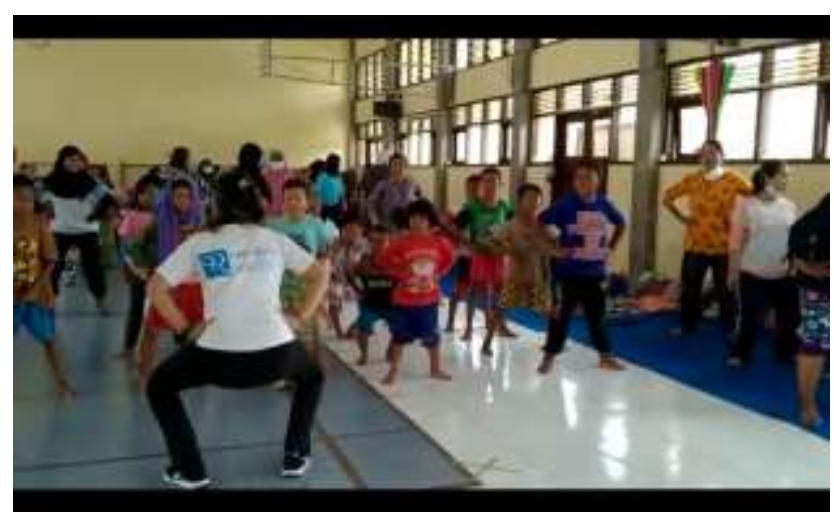

Gambar 3.1 Kegiatan senam aerobic kreasi Bersama masyarakat yang dipandu oleh instruktur senam dari LKP Rafika

\section{Pembahasan}

Banjir bukanlah hal baru bagi warga Pekalongan, daerah pesisir menjadi alasan warga Pekalongan akrab dengan banjir. Namun banjir di awal tahun 2021 ini merendam sebagian besar wilayah Pekalongan cukup lama. Banjir yang berlangsung lebih dari satu pekan tersebut disebabkan oleh curah hujan yang cukup tinggi, yang mengakibatkan 1.546 warga di 6 kelurahan mengungsi di 17 titik [8]. Hal ini menimbulkan kecemasan, dan kehawatiran bagi masyarakat baik orang dewasa maupun anak anak.

Dari situasi diatas tentunya mengundang simpati dari banyak pihak, bantuan logistic juga sudah diterjunkan di titik pengungsian, baik dari pemerintah maupun komunitas. Namun selain bantuan berupa materi sesungguhnya para pengungsi juga sangat membutuhkan stimulasi untuk pemulihan dari ketegangan ketakutan dan kecemasan yang dialami akibat bencana yang terjadi. Prioritas bantuan pasca bencana memang terfokus pada kebutuhan fisik masyarakat terdampak. Selain membangun kembali infrastruktur, perumahan, serta mata pencaharian dan bisnis, penyembuhan mental memang sangat 


\section{Prosiding Seminar Nasional Kesehatan Lembaga Penelitian dan Pengabdian Masyarakat Universitas Muhammadiyah Pekajangan Pekalongan}

penting bagi para korban bencana. Menurut Cat Wise dalam salah satu tulisannya di PBSO News Hour, [9]. Tercermin dari kutipan diatas kami tim pengabdian masyarakat memiliki gagasan untuk andil dalam pemberian dukungan dan berbagi kegembiraan kepada para korban banjir Pekalongan yang berada di pengungsian, untuk memulihkan kembali semangat dan metal para pengungsi di pengungsian. Selain itu bencana yang terjadi di tengah pandemic covid-19 membuat banyak masyarakat yang kemudian abai dan mengesampingkan dengan kesehatan khususnya di titik titik pengungsian. Hal demikian juga mendorong kami untuk mengedukasi dan mengingatkan kembali pada masyarakat tentang pentingnya melaksanakan protocol kesehatan dan menerapkan polahidup sehat.

Dalam praktiknya kami tim pengabdian masyarakat bersama LKP Rafika selaku Lembaga Kursus Pelatihan yang bergerak dalam bidang olahraga senam aerobic memiliki misi yang sama yakni memulihkan kembali mental para korban banjir yang berada di pengungsian. Senam aerobic adalah salah satu olahraga yang mudah diterima oleh seluruh masyarakat baik pria, wanita, anak anak, dewasa, bahkan hingga lanjut usia. Dengan iringan musik yang sedang viral baru baru ini kami mengajak para pengungsi untuk bergerak berolahraga sembari sejenak melepaskan ketegangan kekhawatiran yang dialami oleh korban bencana banjir Pekalongan yang sedang berlangsung.

\section{Kesimpulan}

Pemberian trauma healing menggunakan senam aerobic kepada masyarakat terdampak banjir sangat diperlukan sebagai upaya mengurangi dampak psikologis bencana alam seperti kehawatiran, kecemasan, dan kepanikan yang dialami masyarakat terdampak. Dengan menggunakan senam aerobic kami mengajak para pengungsi untuk bergerak berolahraga sembari sejenak melepaskan ketegangan kekhawatiran yang dialami oleh korban bencana banjir Pekalongan yang sedang berlangsung. Kegiatan yang kami lakukan diawali dengan memberi Pendidikan kepada masyarakat terkait pentingnya PHBS dan 4M, lalu kemudian kami mengajak masyarakat untuk senam aerobic kreasi. Mekipun kegiatan ini dilaksanakan dengan waktu yang terbatas namun melalui pendekatan dan pendampingan secara langsung pesan yang kami sampaikan dapat diterima baik oleh masyarakat.

\section{Ucapan Terima Kasih}

Puji syukur kami ucapkan kepada Allah SWT., atas rahmatnya kami dapat menyelesaikan kegiatan pengabdian masyarakat kali ini dengan lancar tanpa adanya suatu halangan yang berarti. Tidak lupa dengan pihak pihak yang telah mendukung dan membantu pengabdian masyarakat kami diantaranya:

1. Orang Tua kami yang senantiasa menyayangi, mendoakan, dan mendukung kami.,

2. Lembaga Kursus Pelatihan Rafika yang bersedia bekerja sama dengan tim pengabdian masyarakat sebagai instruktur senam aerobik.,

3. Pengurus Pengungsian yang berada di SMK N 2 Pekalongan yang mengizinkan dan mengkondisikan kegiatan pengabdian masyarakat ini., 


\section{Prosiding Seminar Nasional Kesehatan Lembaga Penelitian dan Pengabdian Masyarakat Universitas Muhammadiyah Pekajangan Pekalongan}

4. Program studi Pendidikan Jasmani Fakultas Ilmu Kesehatan dan Dosen pembimbing yang senantiasa mendorong, mendampingi dan membimbing tim pengabdian masyarakat.

5. Universitas Muhammadiyah Pekajangan Pekalongan yang bersedia memfasilitasi dalam mengembangkan potensi dan kreatifitas mahasiswa.

Kami ucapkan banyak terimakasih kepada seluruh pihak yang telah mendukung kelancaran kegiatan pengabdian masyarakat ini, hingga kami dapat menyelesikan penulisan tanpa halangan suatu apapun.

\section{Referensi}

[1] Badan Penanggulangan Bencana Daerah Kabupaten Tanah Laut, "Definisi Bencana menurut Undang-undang Nomor 24 Tahun 2007," 2018. http://bpbd.tanahlautkab.go.id/definisi-bencana-menurut-undangundangnomor-24-tahun-2007 (accessed Feb. 20, 2021).

[2] Pemerintah Kota Pekalongan, "Letak Geografis Kota Pekalongan." https://pekalongankota.go.id/halaman/geografi.html (accessed Feb. 20, 2021).

[3] Syamil Quran. PT.Sygma Examedia Arkanleema, 2009.

[4] D. D. Pramardika, J. Siska, H. Hinonaung, A. J. Mahihody, and G. A. Wuaten, "Terapi Bermain Sebagai Trauma Healing Pada Anak," vol. 3, pp. 167-172, 2020.

[5] O. Makplus, "Definisi dan Pengertian Perilaku Menurut Para Ahli," 2015. http://www.definisi-pengertian.com/2015/07/definisi-pengertian-perilakumenurut-ahli.html?m=1 (accessed Feb. 21, 2021).

[6] Kementrian Kesehatan Direktorat Promosi Kesehatan Masyarakat, "PHBS," 2016. https://promkes.kemkes.go.id/phbs (accessed Feb. 20, 2021).

[7] F. T. Nugroho, "Pengertian Senam Aerobik, Jenis-Jenis, dan Manfaatnya bagi Kesehatan," 2021. https://www.bola.com/ragam/read/4453895/pengertiansenam-aerobik-jenis-jenis-dan-manfaatnya-bagi-kesehatan (accessed Feb. 21, 2021).

[8] A. m Idhom, "Banjir Pekalongan Februari 2021 Lebih 1 Pekan, Pengungsi Masih 1500," tirto.id, 2021. https://tirto.id/banjir-pekalongan-februari-2021-lebih-1pekan-pengungsi-masih-1500-gaiX.

[9] R. Setiawan, "Pentingnya Pemulihan Psikis Para Korban Gempa dan Tsunami," tirto.id, 2018. https://tirto.id/pentingnya-pemulihan-psikis-para-korban-gempadan-tsunami-c3Q7. 